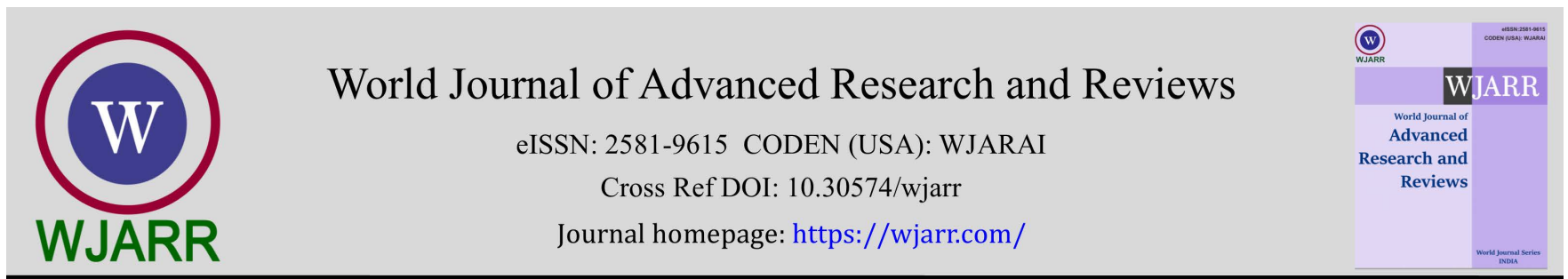

(RESEARCH ARTICLE)

\title{
Reasons for shrinking secondary science student enrollment in Bangladesh
}

\author{
Mohammad Abdul Wahab ${ }^{1}$, Md. Abdus Sattar Molla ${ }^{2,}{ }^{*}$ and Sohana Afrin ${ }^{3}$ \\ ${ }^{1}$ Bangladesh Open University (BOU), Gazipur, Bangladesh. \\ ${ }^{2}$ National Institute of Education (NIE), Nanyang Technological University (NTU), Singapore. \\ ${ }^{3}$ Homing for Education and Social Development Limited (SDL), Mohammadpur, Dhaka.
}

World Journal of Advanced Research and Reviews, 2021, 11(02), 069-080

Publication history: Received on 25 June 2021; revised on 30 July 2021; accepted on 01 August 2021

Article DOI: https://doi.org/10.30574/wjarr.2021.11.2.0349

\begin{abstract}
To cope with the rapid advancement in science and technology and with knowledge explosion, the education policies of the countries in Asia and the Pacific give emphasis on science and technology education as an integral part of formal school education. Some countries have already started implementing new program of science, many countries are in the process of planning but Bangladesh's plan is yet to take shape for the improvement of science curriculum. As a result, enrollment of students in science at the secondary level in Bangladesh has been shrinking gradually. It is imperative to investigate why scope of science education here decreases in the days of scientific advancement worldwide.
\end{abstract}

Thus, the aim of this study is to improve the curriculum, science contents, and methods of teaching science, know-how on the use of process skill, teaching aids and laboratory equipment for teaching science in more meaningful and efficient manner to upright the science student enrollment scenario in place of the unfortunate declining trend in enrollment.

For this, a study was conducted by collecting opinions of Head Teachers, classroom science teachers, education managers and some renowned science educators via questionnaires, focus group discussion (FGD) and interview.

The study revealed that reduced scope of employment, scarcity of efficient science teachers, inadequate supply of science equipment, and above all no 'priority of science' over arts and business studies have been the main causes of shrinking enrollment science students.

Keywords: Science; Enrollment; Shrinking; Sampling; Focus group; Interview

\section{Introduction}

The quality of science education at the secondary level of Bangladesh has been under severe criticism recently [1]. The teaching of scientific facts and the principles is being done theoretically with an absence of empirical observation and evidences [2]. This approach is not conducive to the inculcation of scientific thinking among learners [3]. In this context improvement in curriculum and textbooks alone cannot bring any appreciable changes unless the teachers try to establish linkages between real life problem and updated science curriculum [4][5]. Another lacuna of science teaching is that traditional method of teaching which encourages rote memorization of facts, principles and laws are still without actually understanding them [6]. The results of such an approach are quite disappointing and even the basic concepts have not been developed by the teachers and the learners [7].

These problems in understanding science and low-quality teaching along with still unknown reasons led to the decline in the student enrollment in science at the secondary level [8]. The declining trend actually began much before.

\footnotetext{
* Corresponding author: Md. Abdus Sattar Molla

National Institute of Education (NIE), Nanyang Technological University (NTU), Singapore.
} 
Education writer Masum Billah [9] in his investigative article published in the Daily Star in 2008 made the figure vivid. The data on Secondary School Certificate (SSC) and Higher Secondary Certificate (HSC) Examinations, this writer presented says that in 1990, 42.21\% of SSC examinees were science students, whereas that in 2008 decreased to $23.76 \%$. The figure of HSC science examinees in 1990 was $28.13 \%$. This figure went down in 2008 to only $19.41 \%$. Although some reasons of such decline in science stream examinees were said to be poor teaching standard and lack of laboratory facilities, many reasons are still unknown.

The unknown reasons must be unearthed by worthy investigations. Hence, we attempted the present research done under the purview of 'Teacher Quality Improvement' (TQI) project (working under the Directorate of Secondary and Higher Education [DSHE], Bangladesh) led by the project consultant and the first author of this paper.

\subsection{Statement of the Problem}

There are various constraints and impediments which projected from several forums on science and mathematics education like professional bodies, seminars, workshop, discussion sessions, news media, journals, study report, teachers, students, educationally aware guardians, social workers and employers [10]. These issues on science and mathematics education need to be addressed as early as possible for the welfare of the nation. Having in mind the main drawbacks or obstructions on the way of progress in science and mathematics education in Bangladesh [10], we had conducted a research aiming at finding the reasons of shrinking in science student enrollment, especially at the secondary level (having three sub-stages including: lower, middle and higher) in the country.

\section{Aim}

The aim of the study was to improve the curriculum, contents of science and mathematics, methods of teaching science, know-how on the use of process skill, teaching aids and laboratory equipment for teaching science and mathematics in more meaningful and efficient manner so that the declining trend in student enrollment in science can be thwarted.

\section{Objectives}

- To review the existing curricular materials, processes of teaching and other related facilities to determine strengths and weaknesses of secondary science and mathematics education.

- To review the existing science and mathematics curricula for determining the factors acting as obstacles to enhancement of science and mathematics.

- To identify the reasons of shrinking the rate of science and mathematics students at the secondary level.

- $\quad$ To suggest measures to reduce the trend of shrinking enrollment in secondary science.

\section{Materials and methods}

\subsection{Materials}

Materials used in this study were questionnaires, checklists, Focus Group Discussion schedules and semi-structured interview schedules. In addition, letters to the education administrators, the head teachers, and consent letters to each and every participant (respondent) declaring that they would be kept anonymous in the publication.

\subsection{Methods}

The method of this study was mainly the qualitative one. However, empirical data needed to accommodate the qualitative responses, hence quantitative methods such as Random Sampling was used while collecting responses of the stakeholders. The description follows:

\subsubsection{Review of related literature}

Relevant literature, documents, training reports, progress reports, textual materials (modules), and innovation steps were collected for review to understand the inner causes of shrinking the rate in science and math enrollment [11] .

\subsubsection{Sampling procedure and Sample size}

The study samples were drawn from all the seven administrative divisions (including Dhaka, Chattagram, Rajshahi, Khulna, Sylhet, Barishal and Rangpur) of the country (Mymenshingh Division was created after collection of data for this study). Responses from Head Teachers (opinions), practicing science teachers (opinions), education managers, 
guardians \& students (through Focus Group Discussion), and renowned scientists and/or science educators (by Interview) were collected and analyzed [12].

A total of 15 Head Teachers were selected from schools in each division (out of 160 high schools), and total number of Head Teachers were $15 \times 7=105$ (See Table 1). Selected Head Teachers had various levels of educational and/or professional qualification (See Table 2) so that the sample represent the whole nation.

Table 1 Head Teachers working in Govt. and Non-Govt. schools as participants

\begin{tabular}{|c|c|c|c|}
\hline $\begin{array}{l}\text { Division-wise number of } \\
\text { Head Teachers (HTs) }\end{array}$ & Category-wise school Head Teacher & $\begin{array}{l}\text { Number of } \\
\text { Head Teachers }\end{array}$ & Percentage \\
\hline \multirow{7}{*}{$\begin{array}{l}15 \text { HTs were taken from each } \\
\text { Administrative Division, the } \\
\text { total number being } \\
15 \times 7=105\end{array}$} & \multicolumn{3}{|l|}{ Government School } \\
\hline & Boys School & 15 & $14.19 \%$ \\
\hline & Girls School & 05 & $4.76 \%$ \\
\hline & \multicolumn{3}{|l|}{ Non-Govt. School } \\
\hline & Boys School & 20 & $19.04 \%$ \\
\hline & Girls School & 15 & $14.29 \%$ \\
\hline & Co-Education School & 50 & $47.62 \%$ \\
\hline Total No. of Head Teachers & & 105 & $100 \%$ \\
\hline
\end{tabular}

Table 1 above shows that 47.62\% Head Teachers were working in Co-Education Secondary Schools. Out of 105 Secondary School Head Teachers, 85 (80.95 \%) were working at non-Government schools, while the rest 20 (19.05\%) were managing/heading Govt. schools.

Table 2 Distribution of Head Teachers (HTs) According to Qualification

\begin{tabular}{|l|l|l|l|l|l|}
\hline $\begin{array}{l}\text { SL } \\
\text { No. }\end{array}$ & $\begin{array}{l}\text { Degree obtained } \\
\text { General/ Professional }\end{array}$ & $\begin{array}{l}\text { HTs Without } \\
\text { B.Ed/ M.Ed }\end{array}$ & $\begin{array}{l}\text { HTs having } \\
\text { B.Ed Degree }\end{array}$ & $\begin{array}{l}\text { HTs having } \\
\text { M.Ed Degree }\end{array}$ & Total \\
\hline 1 & BA/B.Sc/B.Com & 10 & 32 & - & 42 \\
\hline 2 & MA/M.Sc/M.Com & 20 & 31 & - & 51 \\
\hline 3 & Others & - & - & 12 & 12 \\
\hline 5 & Total & 30 & 63 & 12 & 105 \\
\hline
\end{tabular}

Table 3 Participating Schools and Classroom Science Teachers

\begin{tabular}{|c|c|c|c|}
\hline Type of Schools & Number of Schools & Number science Teacher & Percentage \\
\hline \multirow[t]{2}{*}{ Govt. Schools } & 1.Boys Schools-30 & 30 schools 4 teachers from each school $30 \times 4=120$ & $28.67 \%$ \\
\hline & 2.Girls Schools-20 & 20 schools 4 teachers from each school $20 \times 4=80$ & $19.1 \%$ \\
\hline \multirow{4}{*}{$\begin{array}{l}\text { Non Govt } \\
\text { Schools }\end{array}$} & 3.Boys School- 40 & 40 Schools $\times 2$ Teachers $=80$ & $19.1 \%$ \\
\hline & 4.Girls School-25 & 25 schools $\times 2$ Teacher $=50$ & $11.9 \%$ \\
\hline & 5.Co-Education School-45 & 45 schools $\times 2$ Teachers $=90$ & $64.3 \%$ \\
\hline & & Total No $=420$ & $100 \%$ \\
\hline
\end{tabular}


Table 2 indicates that out of 105 Head Teachers, 30 had simple Bachelor Degree (Batchelor-10, Masters-20) and their percentage was $28.57 \%$. The large number of the Head Teachers had B.Ed Degree and their percentage was $60 \%$. The rest 12 Head Teachers (8.57\%) had Bachelor Degree with Masters of Education.

A total of 420 classroom Science Teachers were selected from 160 schools. The distribution of teachers of Govt. and Non-Govt. schools are presented in Table 3 below. Selected science teachers were of both sexes (Figure 2.1) and had various levels of educational and/or professional qualification ((See Table 4 and Figure 2 ) so that the sample represent the entire nation.

Table 3 shows that of the 160 secondary school teachers, 50 were teaching in Govt. high schools and 110 in Non Govt. Schools. Out of 50 Govt. Schools, 30 were boys' schools and the rest 20 were girls' schools. Of the remaining 110 Non Govt. Schools, 40 were of boys, 25 were of girls and the rest 45 were Co-education schools. Altogether 420 classroom science teachers were involved in this study.

\subsection{Distribution of science teachers according to gender}

In this study total number of 420 teachers participated of which 140 teachers were female and 280 teachers were male.

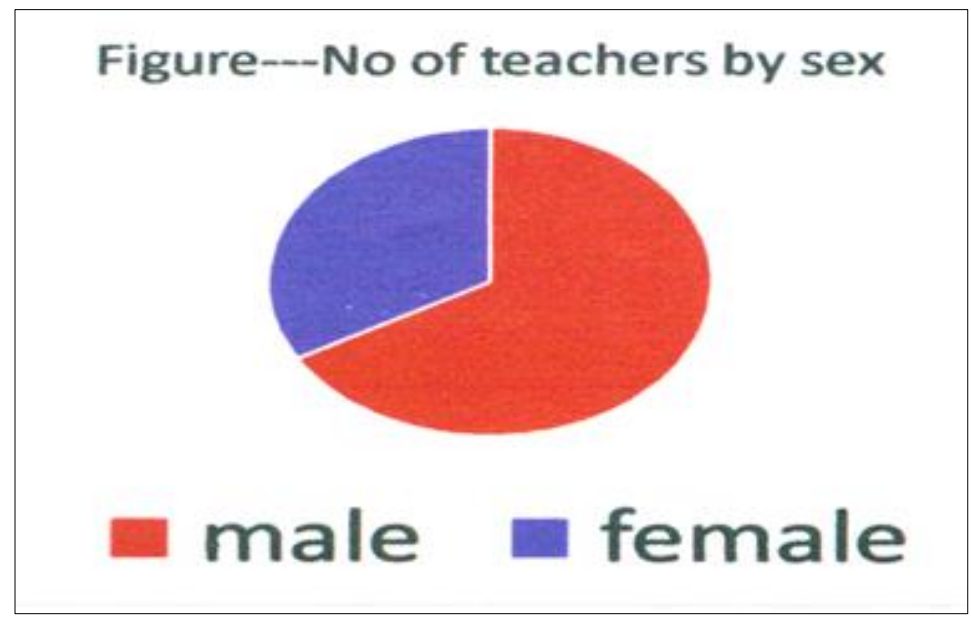

Figure 1 Distribution of science teachers by sexes

Table 4 Distribution of Science Teachers according to professional qualification

\begin{tabular}{|l|l|l|l|l|}
\hline Professional & Without B. Ed or M. Ed & B. Ed & M. Ed & Total \\
\hline BeneraI & & & & \\
\hline M. Sc & 90 & 139 & 55 & 284 \\
\hline Total & 55 & 56 & 25 & 136 \\
\hline
\end{tabular}

There were 420 teachers in the 160 sample schools. The member of male teachers 280 and the female teachers was 140. Table 3 above indicates that out of 420 teachers 90 had Bachelor of Science Degree and 55 teachers had Master of Science Degree. Table 4 further indicates that 195 teachers had Bachelor of Education Degree and 80 had Master of Education Degree. 
World Journal of Advanced Research and Reviews, 2021, 11(02), 069-080

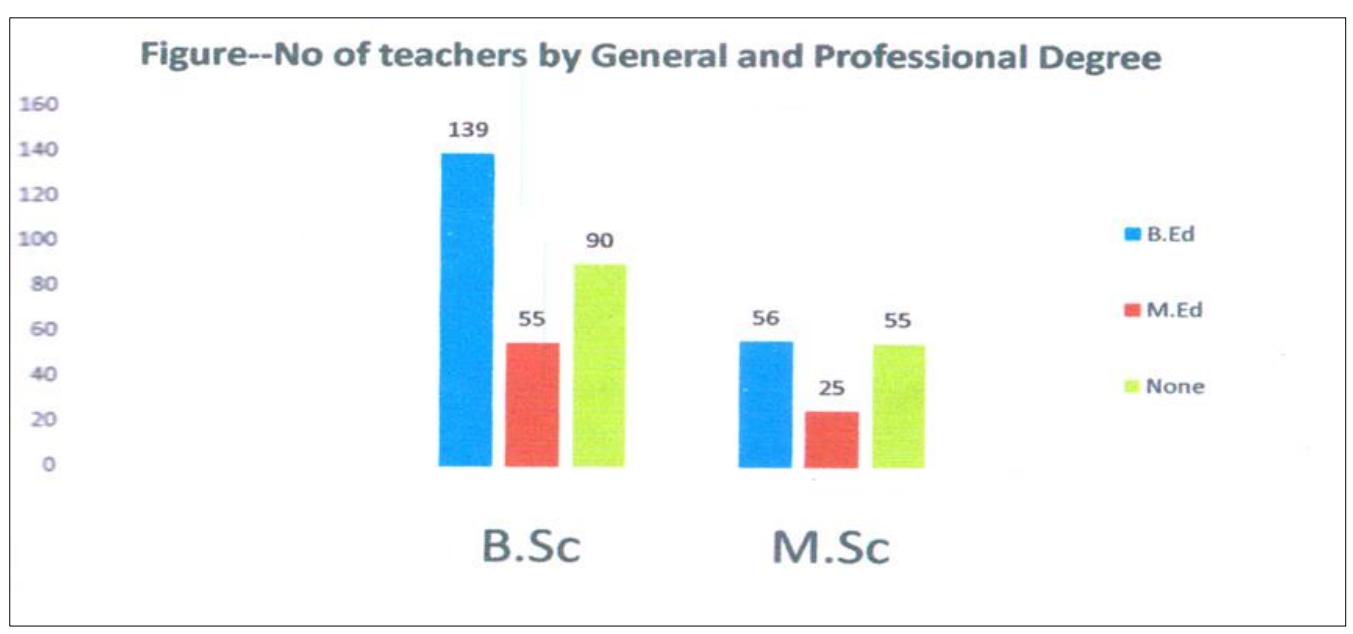

Figure 2 Distribution of Science Teachers according to professional qualification

\subsection{Focus Group Discussion (FGD) sessions, participants and procedure}

Now-a-days, FGDs are used as techniques of qualitative evaluation of much interested issues of national development programs. Discussion with Focus Groups including education administrators, school associations, guardians, science teachers and students were made. The following categories of respondents were drawn for Focus Group Discussion (FGD) sessions. Number of participants taken from each Division were shown in a table (Table 5) below:

Table 5 Participants in Focus Group Discussion (FGD) sessions from each Division

\begin{tabular}{|l|c|}
\hline \multicolumn{1}{|c|}{ Types of participants } & Number of participants \\
\hline SMC and PTA Members & 5 \\
\hline Best Science Teachers & 5 \\
\hline Upazilla Education Officers & 5 \\
\hline $\begin{array}{l}\text { Science teachers teaching at grades 11 and 12 } \\
\text { Classes (Physics-1, Chem-1, Biology-1 and Math-2) }\end{array}$ & 5 \\
\hline Educated guardians/parents & 5 \\
\hline Boy students of Class X & 5 \\
\hline Girl students of Class X & 5 \\
\hline Total FGD participants from each Division & 35 \\
\hline $\begin{array}{l}\text { Thus, the total FGD participants from seven } \\
\text { Divisions }\end{array}$ & $7 \times 35=245$ \\
\hline
\end{tabular}

FGD studies were conducted in 10 locations of 7 Divisions to know about the reasons of declining science enrollment in the secondary schools.

The main purpose of FGD sessions was to come up with a type of consensus on various issues with diverse groups of respondents. After thread-bare discussion and argument, an almost unanimous decision cropped up among the members of the FGD.

\subsubsection{Development of FGD schedule}

A Focus-Group Discussion schedule was developed and tried-out on sample target groups to see its appropriateness and usability. The selected experts of FGD were oriented on the techniques of FGD conduction by organizing a simulation session by some expert facilitators. However, the FGDs were organized in high schools located in Divisional Head Quarters or in District level Secondary schools. 
In FGDs held in 10 locations, a total of 245 participants attended. Of them 35 were School Managing Committee (SMC) members and Parent-Teachers' Association (PTA) members, 35 were 11-12 grade teachers, 35 were educated guardians. In addition, 35 were Education Officers, and Grade X students of both sexes: 35 boys and 35 girls of science group were attendants.

\subsubsection{Pre-induction session of FGD}

After welcoming the invitees and paying good wishes to everybody, FGD facilitators themselves introduced first and then requested the invitees to introduce. At the end of the initial formalities, the facilitators exchanged views and explained the purposes of arranging FGD. Before starting FGD, facilitators explained the working procedures and how they would come to consensus on each issue.

When both facilitators and the invitee participants could conceptualize the FGD working procedures then the process proceeded for FGD.

\subsection{Interview Sessions with science specialists}

A total of 50 Science Specialists were interviewed by specially designed (semi-structured) interview schedule (Table 6).

Table 6 Distribution of science specialists

\begin{tabular}{|l|c|}
\hline \multicolumn{1}{|c|}{ Types of participants } & Number \\
\hline Nationally reputed science educators & 10 \\
\hline Nationally renowned scientists & 05 \\
\hline Best science teachers of secondary schools & 05 \\
\hline Science subjects' specialists & 15 \\
\hline Reputed science journalists & 05 \\
\hline Persons interested in science education & 10 \\
\hline Total & 50 \\
\hline
\end{tabular}

Table 7 Total Sample size

\begin{tabular}{|l|c|}
\hline Various Types of Respondents & Number of Different Types of Respondents \\
\hline Total number of Head Teachers & 105 \\
\hline Total number of Classroom Science Teachers & 420 \\
\hline Total number of Education Managers (FGD) & 245 \\
\hline Total number of science specialists Interviewed & 50 \\
\hline Grand Total of Respondents & 820 \\
\hline
\end{tabular}

\section{Results}

Results in this study are in the form of views and opinions of various types of stakeholders of secondary education in Bangladesh. The stakeholders as participants in this study were selected by sampling that were described in the previous section (materials and methods). The views and opinions collected from Head Teachers, classroom science teachers, education managers, parents, students and science specialists are being analyzed to find reasons of shrinkage in science student enrollment.

\subsection{Reasons for shrinking Enrollment in science (as viewed by HTs)}

The Head Teachers (HTs) were asked to mention the reasons for declining enrollment of students in science group. 
Table 8 Reasons for reducing science student at the secondary level (as viewed by HTs)

\begin{tabular}{|l|l|l|}
\hline SL. No. & \multicolumn{1}{|c|}{ Reasons } & Percentage \\
\hline 1 & The contents of science in textbooks (syllabus) larger than in other two groups & $80 \%$ \\
\hline 2 & The inclusion of fewer real-life contents in science curriculum & $39 \%$ \\
\hline 3 & The Science Textbooks being difficult to read & $65 \%$ \\
\hline 4 & Inadequate qualified science teachers in the school & $84 \%$ \\
\hline 5 & Shortage of trained science teachers & $68 \%$ \\
\hline 6 & For arranging practical classes equipment and chemicals & $75 \%$ \\
\hline 7 & Science Teachers are overloaded with class & $75 \%$ \\
\hline 8 & Faulty assessment system & $55 \%$ \\
\hline 9 & Science graduates are treated as equal to other graduates in job & $78 \%$ \\
\hline
\end{tabular}

They gave their thoughtful views about the decline in enrollment of students in the statements tabulated. It is obvious that the Head Teachers adjudged science contents as over-loaded (80\%), that there was no better scope of job for the science graduates (78\%), and inadequacy of qualified science teachers (84\%) caused the shrinkage in science enrollment the most. Faulty assessment system (55\%) and scarcity of real life science contents (39\%) were the least responsible ones.

\subsection{Measures to increase science student enrollment (as suggested by HTs)}

The Head Teachers were asked to give their opinion to solve the problems of declining enrollment of students of science groups of secondary level. They suggested a number of measures that were as follows:

- To make teachers aware of their duties and responsibilities

- To increase number of science teachers in the school

- To make practical classes enjoyable and increase the number of practical classes

- To organize science fairs in every school

- To ensure teaching science with teaching aids

- To appoint subject-based teachers to teach science subjects

- To make adequate arrangements for training of science teachers

- To teach science at primary level with teaching aids

- To arrange separate room for science classes

- To enhance capacity of science teachers by deputing higher training organizations

- To establish science clubs and use these clubs to attract students to science education

- To organize meetings in communities to exchange views with community members on the importance of science education

- To give scholarship to poor and meritorious students so that they can pursue science education

\subsection{Practical classes in rural secondary schools (as science teachers viewed)}

As many as 420 science teachers of 160 schools were included in the study. They were asked about the frequency of practical classes held in rural secondary schools. Their views are presented in 9 below.

Table 9 Status of holding practical classless in rural secondary schools

\begin{tabular}{|c|c|c|}
\hline Occasionally & Rarely & Not at all \\
\hline $145(34.42 \%)$ & $180(42.85 \%)$ & $95(22.62 \%)$ \\
\hline
\end{tabular}




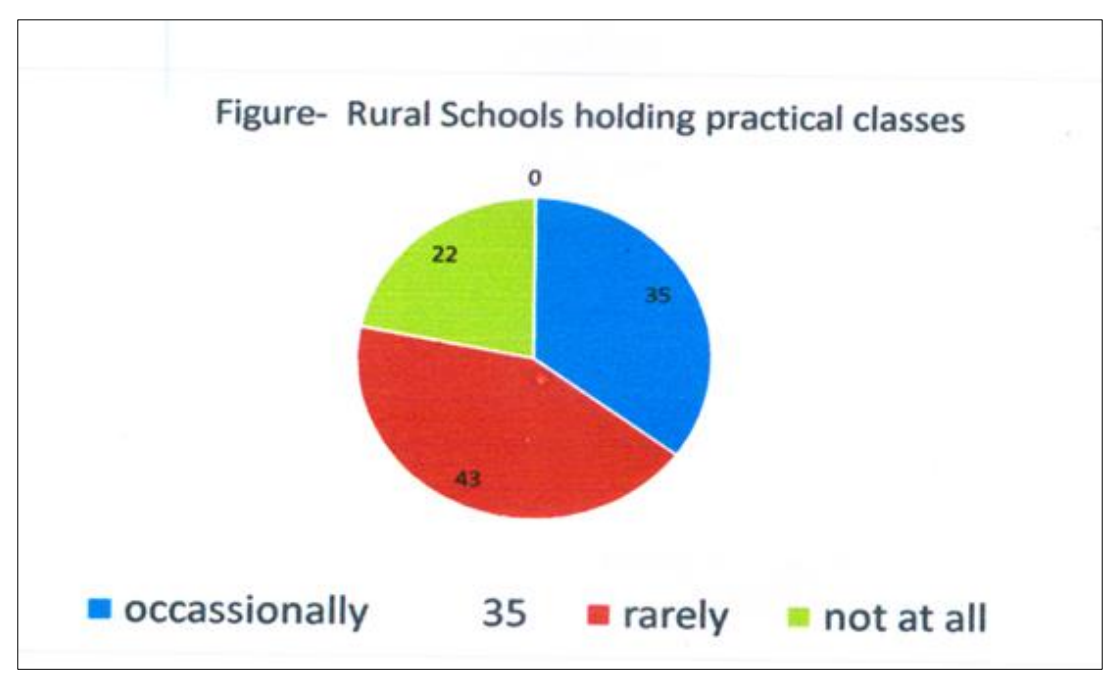

Figure 3 Status of holding practical classless in rural secondary schools

Fig 3 indicates 34\% rural school occasionally arrange practical classes, $43 \%$ schools organized practical classes rarely and $23 \%$ schools not organized practical classes at all.

\subsection{Reasons of declining science student enrollment as found from FGD}

The FGD facilitators first presented the issues why science student enrollment were decreasing. Different invitee groups presented arguments in different prospective. After long argument in favor and against the issues, all invitees came up with the following reasons:

- Financial problem of families

- Lack of awareness of guardians about science

- Too wide syllabus of science subjects

- Lack of required equipment in schools

- Science subject's topics are difficult to understand

- Students have little interest to study science

- Long syllabus of science subjects including physics

- Syllabus is too wide compared to that of other two groups

- Little scope in Bangladesh to apply science education in real life

- Parents are not interested to see that their wards study science

- There is little scope of pursuing higher studies in science in the country

- Shortage of science teachers in schools

\subsection{Suggestion for popularizing science Education at the secondary level}

Respondents were asked to suggest the probable measures that should be taken to popularize science Education at the secondary level. The respondents suggested the following measures:

- Program on science topics should be organized in the media

- SMC members can be encouraged to play some role to monitor students to pursue science education

- Practical classes having realistic linkage with real life situations should be increased

- Schools should buy books related with scientific activities and it should be ensured that such books are properly used by students and teachers

- It should be ensured that science students can use scientific equipment

- Steps should be taken to remove science phobia from students

- Steps should be taken to increase awareness of guardians about science education

- Science fairs should be organized at schools

- Number of practical classes should be increased

- Steps should be taken to appoint subject-based science teachers

- Science education should be made popular at primary level 
- Steps should be taken to make science attractive to kids in early stages

\subsection{Science specialists' views (as gathered from interviews)}

The science specialists were asked to give their concerted views on the reasons for which the students of science presently decreasing at the secondary level in Bangladesh. The science specialists given views are presented in the following table (Table 10)

Table 10 Reasons of Declining Science Students (viewed by science specialists)

\begin{tabular}{|c|l|c|c|}
\hline Sr. No & \multicolumn{1}{|c|}{ Reasons } & Number & Percentage \\
\hline 1. & Study of science is difficult & 45 & $90 \%$ \\
\hline 2. & Study of science requires private tutors & 50 & $100 \%$ \\
\hline 3. & Present secondary science is difficult and tough & 40 & $80 \%$ \\
\hline 4. & Science education is expensive & 45 & $90 \%$ \\
\hline 5. & Students like to study easy subjects & 40 & $80 \%$ \\
\hline 6. & Weak preparation in science at the primary level & 35 & $70 \%$ \\
\hline 7. & Crisis of capable and devoted science teachers & 50 & $100 \%$ \\
\hline 8. & Science curriculum is over-loaded & 45 & $90 \%$ \\
\hline 9. & Very few practical classes were arranged & 50 & $100 \%$ \\
\hline 10. & Crisis of good and easy science books & 45 & $90 \%$ \\
\hline 11. & Inadequate science equipment in the science laboratory & 40 & $80 \%$ \\
\hline 12. & Due to the lack of proper training, science teachers fail to & 45 & $90 \%$ \\
\hline 13. & Lack of interest among teachers to teach science & 43 & $86 \%$ \\
\hline 14. & Science exhibition and science fair were not arranged regularly & 40 & $80 \%$ \\
\hline
\end{tabular}

\subsection{Science Process Skills important to Science Specialists}

The specialists were asked to mention the process skills that encourage students towards studying science. The science education specialists opined that science should be taught in a way that the learners develop basic and fundamental concepts. The learners should learn to work as scientists and explore the facts themselves through enquiry, observation and experimentations.

Table 11 The Process Skills chosen by Science Specialists

\begin{tabular}{|l|l|c|c|}
\hline Sr No & Name of Process Skills & Choice of Specialists & Percentage \\
\hline 1. & Observation & 50 & $100 \%$ \\
\hline 2. & Classification & 50 & $100 \%$ \\
\hline 3. & Recording and communication & 50 & $100 \%$ \\
\hline 4. & Use of numbers & 45 & $90 \%$ \\
\hline 5. & Estimation & 50 & $100 \%$ \\
\hline 6. & Measurement & 50 & $100 \%$ \\
\hline 7. & Asking questions & 50 & $100 \%$ \\
\hline 8. & Formulating hypotheses & 40 & $80 \%$ \\
\hline 9. & Prediction & 35 & $70 \%$ \\
\hline
\end{tabular}




\begin{tabular}{|l|l|c|c|}
\hline 10. & Inference & 45 & $90 \%$ \\
\hline 11. & Experimentation & 50 & $100 \%$ \\
\hline 12. & Controlling Variables & 40 & $80 \%$ \\
\hline 13. & Making Operational definition & 40 & $80 \%$ \\
\hline 14. & Preparing Models & 35 & $70 \%$ \\
\hline 15 & Interpreting Data & 40 & $80 \%$ \\
\hline 16 & Manipulative skills & 45 & $90 \%$ \\
\hline
\end{tabular}

\section{Discussion}

The results of analyzing the data were carefully reviewed. Based on the review of data analysis and matching responses of each type of respondents the general opinion revealed that enrollment in science group at secondary level was continuously declining. This finding has similarity to BANBEIS (2017) [8]. Choudhury (2009) [13] found science education difficult for students mainly because there were shortage of qualified teachers and lack of required equipment. Her study also revealed good grades obtained in business studies easily and lack of job opportunity for science graduates as reasons for declining science enrollment. Yeasmin and Mahmud (2019) [14] in a research, found lack of good and qualified teachers, non-use of equipment and chemicals (whatever have), old and unattractive teaching methods, and teachers' meager salary as causes of decline in science student enrollment. So, they recommended increase in teachers' salary, emphasis on better teaching and creation of better jobs for science graduates. These studies revealed very similar findings to the present one. Thus, comparing the findings discussed above and collating the views gathered from different groups of respondents and suggestions given by different categories of respondents in the present study, the findings can be summarized as follows:

- In Govt. schools there are 4 science teachers per school who have degree level subjects (Physics, Chemistry, Mathematics), but private schools usually lack such teachers.

- Science education is expensive and difficult.

- Schools generally suffer from crisis of appropriate equipment for teaching.

- Some contents of science have not been taken from real life situation.

- Science books are too voluminous, the language is difficult.

- Students from other two groups (Humanities and Business Studies) said that they do not like science because they are weak in Mathematics and have science phobia.

- The science specialists identified as many as 11 causes that pushed out the students from the study of science and mathematics.

- Due to the poor condition of laboratory and having no arrangement of regular practical classes, students did not opt for science.

- In the job market, graduates in science and in others subjects are given almost equal weightage.

- Studying in science stream is costlier and more time-consuming.

- In science process skills study, teachers were reluctant as they lack in knowledge and understanding about process skills.

- Inadequate number of qualified science teachers in the school also contributed to shrinkage in science student enrollment.

- Content of science curriculum are larger than in other two groups

- Science teachers are over-loaded with classes; this bars quality teaching.

- As science subject renders difficult to understand, steps should be taken to make science attractive to kids in the early stages at the primary level.

\section{Conclusion}

In this study 4 different types of responds were utilized with a view to receiving information, views, comments, suggestion to address the reasons of declining student at the secondary level of science education in Bangladesh. The general finding is that in Bangladesh, overall, there is absence of knowledge -based society, neither does have any scope to promote development of knowledge-based society shortly. Implementing the results of this study may enhance teaching standards at the classroom level which will prove to be an enormous task as this will involve massive change in secondary science education. For a country like Bangladesh this is not difficult but constant effort is immensely 
necessary. It is hoped that the study will provide adequate edifice for developing science education based on real life situation.

\section{Recommendations}

The findings of the study brought to light the causes for which enrollment in science group at secondary level is continuously declining. Based on the findings number of recommendations have been made to address the identified problems. The recommendations are:

- The study indicates that one of the main reasons for students not to take science group at Grade 9 is too heavy in science curriculum compared to curriculum of others two groups. It is recommended that curriculum of secondary level science be simplified.

- As study of science requires more merit, time and money, science needs to receive priority over business studies and humanities.

- Science teachers' salary should be increased so that their more laborious job is incentivized.

- Teachers need to be provided with adequate in-service training to enable them facilitate science learning more effectively.

- Investigative approach (inquiry) is to be employed as much as possible in the secondary level, if not in the primary.

- Adequate job opportunities need to be created for science graduates so that they do not feel deprived of their dues.

- Community-based science fairs have been found to make significant impact on popularizing science education among students and the guardians. Science fairs should be organized in schools or school communities.

- School Management Committees (SMCs) have the most important role in the management of secondary schools. SMC members can be encouraged to play some role to motivate students towards science education.

- Schools should buy books related to science and it should be ensured that such books are used by teachers.

- Poor meritorious students do not take science group because of high expenses. There are many development projects in different parts of the country. The country is carried by government agencies or NGOs. Poverty stricken parents of meritorious students can be included as beneficiaries of development projects so that their wards can pursue science education.

- $\quad$ There are few students who are involved in science research work/study in the early stage of educational life. Steps should be taken to identify the innovative scientific work of such students and they be rewarded so that they can continue such work side by side their studies and can ultimately help to popularize science education.

- A science club can play vital role in creating interest among young people towards science education. Science club can be established in different parts of the country and used to attract students to science education.

- There should be a strong measure to enforce compulsory and regular holding of practical class after completion of each unit, at least one practical class per week.

- $\quad$ Step should be taken to remove science phobia among the students.

- Appoint subject-based teachers to teach science subjects.

- Crises of competent science teachers should be removed by imparting need-based teachers training.

- Laboratories in schools should be enriched by providing science equipment free of cost.

- The findings of this study warrant concerted efforts to promote the development of a knowledge-based society; new knowledge created would be linked with prevalence of a science-oriented culture.

\section{Compliance with ethical standards}

\section{Acknowledgments}

The authors gratefully acknowledge the generous permission of using the data collected by the Teacher Quality Improvement (TQI) project under the Directorate of Secondary and Higher Education (DSHE), Bangladesh.

\section{Disclosure of conflict of interest}

The authors have jointly contributed in the manuscript, and there is no conflict of interest among the authors. 


\section{Statement of informed consent}

Permission from education administrators and the head teachers was duly sought and received. Consent letters to each and every participant/respondent (declaring that they would be kept anonymous in the publication) was supplied and received signed copies before starting of collecting data from them.

\section{References}

[1] Aziz MA, Ali T. Training Manual for Secondary Curriculums Wing, NCTB, Dhaka. 2010.

[2] Rasul GM, Doha S, Haider SM, Wahab MA. General Science (Textbook) Classes IX- X, NCTB. Dhaka. 2014.

[3] Sharma U. Teaching inclusive subject for changing habit. Indore University, Indore, India. 2012.

[4] Wahab MA. Developing a program of curricular content and methodology in the areas of science and agriculture for TTCs of Bangladesh. Unpublished PhD thesis, University of Delhi (CIE), India. 1984.

[5] Ministry of Education. National Education Policy 2010, Dhaka. MOE, Govt. of Bangladesh. 2010.

[6] Muttaqui IA, Tapan SM. Science Teacher Guide for class VII, NCTB, Dhaka. 2009.

[7] Anderson HO. Reading in Science Education for the Secondary School. Macmillan, New York. 2009.

[8] BANBEIS. Educational Database, "Bangladesh Education Statistics. 2018.

[9] Billah, M. (2008). Science education declines in the Age of Science. The Daily Star. October 28, 2008, Dhaka.

[10] Doha S, Rasul GM, Wahab MA, Khan ZI. General Science for class VIII, NCTB, Dhaka. 2009.

[11] Kerlinger FN. Behavioral Research: A conceptual Approach, Holt Rinehart. Inc, New York. 1979.

[12] Bush, M. B. (2009): A Survey of research in education, M.S. University, Boroda, India.

[13] Choudhury SK. Problems and Prospects of Science Education in Bangladesh. AIP Conference Proceedings 1119. American Institute of Physics. 2009; 83.

[14] Yeasmin S, Mahmud MD. Acquiring Scientific and Technological Proficiency: State of Science Education in Bangladesh, Asian Journal of Humanity, Art and Literature. 2019; 6(2): 169-184. 